\title{
Compensating a Legal Person for Moral Damage in Jordanian Law
}

\author{
Mohammad Mahjoob Almaharmeh ${ }^{1}$ \\ ${ }^{1}$ Sheikh Noah College of Sharia and Law, The World Islamic Sciences and Education University, Jordan \\ Correspondence: Dr. Mohammad Mahjoob Almaharmeh, Sheikh Noah College of Sharia and Law, The World \\ Islamic Sciences and Education University, Jordan. Tel: 07-7930-3530. E-mail: \\ Mohammad.Almaharmeh@wise.edu.jo
}

Received: October 14, 2021

Accepted: December 24, $2021 \quad$ Online Published: January 3, 2022

doi:10.5539/jpl.v15n2p1

URL: https://doi.org/10.5539/jpl.v15n2p1

\begin{abstract}
The issue of compensating the legal person for the moral damage it causes to it has raised a great argument of controversy in Jordan, especially in light of the refusal to recognize the rights attached to the natural person of the legal person. This research came to identify the legal nature of the legal personality and the moral damage and the position of the Jordanian law on it, and to determine the feasibility, adequacy and appropriateness of the legal texts contained in the Jordanian civil law in knowing the extent to which the legal person may be compensated for moral damage. Using the opinions of jurists and judicial and explanatory decisions, the researcher has found that moral damage has multiple forms, a research that arises from the act and assault carried out by the aggressor. As a result, it is not appropriate to limit moral damage to rigid legal texts based on what is stated in the legislation and decisions of the esteemed Court of Cassation, as the researcher recommends. The Jordanian legislator should include general provisions clarifying the civil liability of the legal person, and the researcher recommends a separate chapter in the civil law to talk about the moral damage and its multiple meanings and aspects and how to rule for compensation and claim it.
\end{abstract}

Keywords: legal person, compensation, moral damage, personal rights, Jordan legislations

\section{Introduction}

Most of the legislation recognizes the existence of groups, which is a mixture of the natural and voluntary union of man with other persons and aims to achieve a specific legal goal and is recognized by the law. The name of the legal or legal persons ${ }^{(1)}$, and the person in the legal term is the one who enjoys the legal personality, that is, who is able to acquire rights and bear obligations, and this personality is originally established for the human being, which is what is called the natural person. Persons or money, which is what is called legal persons. ${ }^{(2)}$

Since the legal personality is established for practical considerations other than the human being, i.e. for the socalled legal person, the law recognized these groups with the legal personality and made them a personality independent of the personality of the individuals who made them up in order to enable them to achieve their purposes $^{(3)}$, so the legal person is every group of people targeting a common purpose or each group From the funds allocated to achieve a specific purpose and grants legal personality to the extent necessary to achieve this purpose $^{(4)}$.

According to Jordanian legislation, legal persons are called another term, which is legal persons, and this is in accordance with the text of Article (50) of the Jordanian Civil Code that legal persons are: the state and municipalities under the conditions specified by law, public institutions and other facilities granted by law a legal personality, and bodies Religious sects for which the state recognizes a legal personality, endowments, commercial and civil companies, associations and institutions established in accordance with the provisions of the law, and every group of persons or funds for which a legal personality is established in accordance with the text of the law.

(1) Yahya Ahmed Mowafi, The legal person and his responsibilities under civil, administrative and criminal law, Mansha'at al-Maaref, Alexandria, 1987, p. 15.

${ }^{2}$ ) Iyad Abdul-Jabbar Maluki, Responsibility for things and its application to legal persons in particular, a comparative study, University of Baghdad, 1979, p. 279.

(3) Yahya Ahmed Mawafi, The legal person and his legal responsibilities, previous reference, p. 15

(4) Iyad Abdul-Jabbar Molouki, Responsibility for Things and Its Application to Legal Persons, previous reference, p. 279 
A legal person enjoys all rights except what is inherent in a person's character within the limits established by law, and legal persons are subject to the provisions of their own laws ${ }^{(5)}$. To carry out its activity and not be legally bound except by natural persons who represent it and who put their awareness, will and activity at its service ${ }^{(6)}$.

And by looking at the Jordanian civil law, legal persons are divided into two parts: public moral persons, such as the state and governorates, and private moral persons, such as companies and associations. For a legal person to engage in a natural activity such as a natural person, he arranges his civil or criminal responsibility, and then jurisprudence and the judiciary have agreed that criminal responsibility is not attributed to only a natural person, so the crime and punishment are personal and cannot be attributed to the legal person. Civil morality means that his obligation is preoccupied with a financial obligation that he incurs in the form of compensation leading to the injured party. ${ }^{(7)}$

And if in the past some jurisprudence objected to the permissibility of a legal person being held civilly responsible for his personal action, while he is a Muslim, in principle at least, that it is not permissible to hold him criminally responsible or to impose a penalty on him because of his lack of will and the discrimination that allows for the fault to be attributed to him, which is a condition for the establishment of civil liability Modern jurisprudence is abandoning the basic idea in that, which considers the legal person not a real person, but merely a legal person, and embraces the idea of the real personality, which considers that the legal person is a will expressed by its representatives from its members or from the bodies formed by them such as its board of directors, the head of this board or the managing director. The administration or any member authorized by the competent body may delegate him to carry out a work of the legal person, and accordingly the prevailing trend in jurisprudence and the judiciary has become that the legal person can be questioned by a civil ${ }^{(8)}$. It is permissible for a legal person to be held liable for tort, just like that of a natural person. Civil liability, unlike criminal responsibility, lies with the money of the legal person. Therefore, the legal person may be held accountable for the mistakes committed by its representatives or bodies. Examples of these mistakes are when a company manager dismisses a worker without justification or tramples on A pedestrian train driver or a company imitation of a trademark of another company. ${ }^{\left({ }^{9}\right)}$

And the legal person is liable for this civil liability for his personal action, to which all provisions of civil liability apply, provided that the harmful act was committed by the legal representative of the legal person in the name of the latter and for his account and within the limits of the powers granted to that legal representative. This applies to private legal persons and public legal persons, and both The two types of persons can be realized their responsibility for the personal act, as well as their responsibility for the actions of their subordinates, such as workers, employees and employees, as well as their responsibility for doing things of various kinds, ${ }^{(10)}$ Through this research, we will try to identify the compensation of a legal person for moral damage in Jordanian law.

\subsection{Research Problem and Its Importance}

Responsibility for the harmful act is one of the most important civil law issues and one of its sections is moral damage, which is every harm that affects the human being in his exposure, emotion or feeling. The extent to which the legal person may be compensated for the moral damage.

\subsection{Research Aims}

The aim of this research is to identify the legal nature of the legal personality and the moral damage and the position of the Jordanian law on it and the extent to which the legal person may be compensated for moral damage in Jordanian law.

The research mainly aims to find solutions to the controversy raised by the Jordanian courts with their differences on the issue of the legal person's right to be compensated for moral damages caused by the violation of his private rights such as intellectual property rights and abuse of his reputation and his legal and commercial status.

\subsection{Research Methodology}

The research relied on following the analytical descriptive research method for the provisions and rules of the Jordanian civil law, drawing on the opinions of jurists and judicial and explanatory decisions related to this subject

$\left({ }^{5}\right)$ See Articles (51) and (52) of the Jordanian Civil Code.

$\left(^{6}\right)$ Solomon Marks, Al-Wafi, previous reference, pg. 416

( 7$)$ Abdul Hakim Fouda, Civil Compensation, previous reference, p. 139

$\left({ }^{8}\right)$ Solomon Mark, Al-Wafi, previous reference, p. 523.

$\left({ }^{9}\right)$ Ramadan Abu Al-Saud, Mediator in Explanation of the Introduction to Civil Law and the Introduction to Law, Especially the Egyptian and Lebanese, University House, for Printing and Publishing, Beirut, 1985, p. 370.

$\left({ }^{10}\right)$ Solomon Mark, A1-Wafi, previous reference, pp. 524-525. 
whenever the need arises.

\section{The First Topic: Define What is Meant by a Legal Person}

The idea of a legal personality is considered by some jurists a metaphorical creation based on assumption, while others consider it a legal fact, and by law the legal personality is no longer limited to the natural person, but the legal personality exists, so what is the legal person, and the legal person is often entrusted to others to carry out his obligations, which is entrusted by the legal person under an agreement, and in this section, the definition of what is meant by the legal person will be addressed through three demands as follows:

- $\quad$ The first requirement: Defining the legal person, its types and characteristics

- The second requirement: the legal nature of the legal personality

- The third requirement: the elements of the legal person

\subsection{The First Requirement: Definition of a Legal Person and Its Types}

During this requirement, the legal person will be defined and the types of legal persons will be defined, as follows:

\subsubsection{First Branch: Definition of a Legal Person}

There are many definitions of the legal person, as part of the jurisprudence defines it as a group of people or a group of funds with the aim of achieving a specific purpose, and the law recognizes him as a legal personality, and thus becomes capable of establishing rights for him, obligating him with duties, and looking at him abstract from the established persons. him or his constituent funds ${ }^{(11)}$. It is a group of people or funds aimed at achieving a specific goal ${ }^{(12)}$ and it was also defined as a moral existence that is neither perceptible nor perceptible to sense, and enjoys the legal personality to enable it to receive rights and bear obligations ${ }^{(13)}$, and the legal person has an independent and self-contained existence, and thus can be He owns and contracts with others, and he is both a creditor and a debtor, as he is like a natural person with a special liability, not mixed with the liabilities of the natural persons of which he is composed ${ }^{(14)}$

The existence of the legal person extends to institutions and public administrations and the state, and to many companies and associations, because each of them has a legal personality, separated from the natural personalities that represent it or that work in its interest, so it enjoys the capacity of obligation and the capacity to perform ${ }^{(15)}$.

Thus, public moral persons were defined as those persons that carry out work and tasks related to society, aiming to achieve a public interest, and which are the prerogative of the public authority. They are initially subject to public law and include the state, the municipality or the governorate, public groups and public, administrative, industrial and commercial institutions ${ }^{(16)}$.

The Jordanian legislator is usually keen to explicitly stipulate that public law persons enjoy legal personality, such as the Ports Corporation Law ${ }^{(17)}$ the Royal Jordanian Law ${ }^{(18)}$, the Public Transport Corporation Law ${ }^{(19)}$ the Radio and Television $\mathrm{Law}^{(20)}$, and the Universities Law ${ }^{(21)}$ although there are some Facilities that do not have an independent legal personality, but rather follow the public legal person, such as government hospitals, which are attached to the Ministry of Health, and government schools are attached to the Ministry of Education ${ }^{(22)}$.

The recognition of a legal personality has important consequences, which were referred to in Article (51) of the

${ }^{11}$ ) Al-Attar, Abdel Nasser, (1979), Introduction to the Study of Law and the Application of Islamic Law, Al-Saada Press, Cairo, p. 314

$\left({ }^{12}\right)$ Al-Wakeel, Shams El-Din, (1968), Principles of Law, 1st Edition, Mansha'at Al-Maaref for Publishing, Alexandria, p. 339

$\left({ }^{13}\right)$ Bariri, Mahmoud Mukhtar, (1985), the legal personality of the commercial company, Dar Al-Fikr Al-Arabi, Cairo, p. 9.

$\left({ }^{14}\right)$ Al-Sadda, Abdel Moneim Farag, (1998), The Origins of Law, Dar Al-Nahda Al-Arabiya Publishing, Cairo, p. 507.

$\left({ }^{15}\right)$ Al-Baqmi, Salih Yen Zabin Al-Marzouqi, (1406 AH), the joint stock company in the Saudi system: a comparative study of Islamic jurisprudence, Center for Scientific Research and the Revival of Islamic Heritage, Umm Al-Qura University, Riyadh, p. 192.

$\left({ }^{16}\right)$ Morcos, Suleiman, (1957), Introduction to Legal Sciences, Cairo, p. 672.

$\left({ }^{17}\right)$ Article (3/a) of the Ports Corporation Law No. (36) of 1985 states that "a governmental institution called the Ports Corporation with a legal personality shall be established by virtue of this law."

$\left({ }^{18}\right)$ Article (3/a) of the Royal Jordanian Law No. (60) of 1969 states that “...the institution shall have a legal personality.”

$\left({ }^{19}\right)$ Article (3/a) of the Public Transport Corporation Law No. (19) of 1985 states that "a corporation called the Public Transport Corporation shall be established in the Kingdom with a legal personality."

$\left({ }^{20}\right)$ Article (3/a) of the Radio and Television Law No. (29) of 1985 states that "a public official institution enjoying a legal personality shall be established in the Kingdom."

$\left({ }^{21}\right)$ Article (3/a) of the Universities Law No. (29) of 1987 states that "the university has a legal personality."

${ }^{(22)}$ Judgment of the Supreme Court of Justice: December 16, 1973, Journal of the Jordanian Bar Association, 1974, p. 90 
Jordanian Civil Code, which are ${ }^{(23)}$ :

a. Independent financial disclosure.

NS. Eligibility within the limits specified in its establishment deed or established by law.

NS. Litigation right.

Dr. An independent domicile, and his domicile is considered the place where his management center is located, and companies whose headquarters are abroad and have activity in the Hashemite Kingdom of Jordan, their headquarters, according to internal law, is the place where the local administration is located.

From the foregoing, a legal person can be defined as a group of people and funds established to achieve a set of purposes, which results in the creation of a distinct and independent legal person from those persons who constitute it, and who is qualified to acquire rights and assume obligations in his name and for his own account.

Therefore, it is legally recognized that the legal person contracts through his legal representative ${ }^{(24)}$ and enjoys all rights except what is inherent in the capacity of a natural person ${ }^{(25)}$, and is also responsible in contract or tort, and is obligated to pay the compensation that is due to him due to the acts committed by his representatives harmful to his name and account ${ }^{(26)}$.

\subsubsection{Second Branch: Types and Characteristics of a Legal Person}

During this section, the types of legal persons will be defined, as follows:

\subsubsection{First: Types of Legal Persons}

By extrapolating the text of Article 50 of the aforementioned Jordanian Civil Code, we see that it touched on legal persons, calling them legal persons, and defining them as follows:

1) The state and municipalities under the conditions specified by law, public institutions, and other establishments that are granted legal personality by law.

2) Religious bodies and sects, for which the state recognizes a legal personality.

3) Endowment.

4) Commercial and civil companies.

5) Associations and institutions established in accordance with the provisions of the law.

6) Every group of persons or funds whose legal personality is established in accordance with the text of the law.

Where there are many and different legal persons, we find that they are of two main types, they are public and private legal persons, and what we are concerned with here is the private legal persons who are subject to private law, such as commercial and civil companies, endowments, religious bodies, associations and institutions, and every group of persons and funds, whose identity is established by virtue of a provision in the law.

That is, these private legal persons have a private goal and achieve material profit, as in commercial companies, or the goal is charitable, such as charitable societies and religious organizations ${ }^{(27)}$.

\subsection{The Second Requirement: The Legal Nature of the Legal Person}

Opinions differed about the essence and nature of the legal personality, is it a tangible reality or is it just a ploy to reach certain goals, and legal researchers have identified three directions about this, which can be clarified as follows:

\subsubsection{The First Trend}

He sees that the legal personality is nothing but a legal metaphor, aiming to simplify matters from a practical point

${ }^{23}$ ) This article corresponds to Article (55) of the Syrian Civil Code, Article (53) of the Libyan Civil Code, and Article (50) of the Algerian Civil Code

${ }^{(24)}$ Article (51-3) of the Jordanian Civil Code states that "a legal person shall have a representative to express his will."

$\left.{ }^{(25}\right)$ Article (51-1) of the Jordanian Civil Code states that "a legal person enjoys all rights, except for those that are inherent in a person's natural character, within the limits established by law."

$\left.{ }^{(26}\right)$ Boukhazna, Mabrouk, (2010), The Criminal Responsibility of the Legal Person in Algerian Legislation, Al-Wafa Legal Library, Cairo, p. 34.

${ }^{(27)}$ Al-Attar, Abdel Nasser, Introduction to the Study of Law and the Application of Islamic Law, previous reference, p. 319. 
of view ${ }^{(28)}$.

\subsubsection{The Second Trend}

The proponents of this trend see that the legal personality is a realistic reality and there is no assumption in it.

Or at least, not everything in it is an assumption and not everything in it is a fact. Its objective element is a fact, and its formal element is based on the assumption of the validity of this group of people or funds to acquire rights and perform duties. According to this trend, the legal personality exists without the need for a legal text, but rather as soon as the company is formed. Horio the French said this theory with regard to legal persons such as the state and municipalities, and he called it the theory of real existence ${ }^{(29)}$.

The Jordanian legislator has recognized the legal personality of the human being, making him fit to acquire rights and bear obligations. He also has the ability to express his will and dispose of his affairs within the limits set by law (Articles 30-49) of the Jordanian Civil Code.

However, the social interest required the legislator's recognition of the legal personality, not for a person alone, but for a group of people converging on a specific goal, or for a group of funds earmarked to achieve a specific purpose. He has rights and duties, and therefore he is fit to be a subject for addressing the law; And to be a legal person in accordance with the provisions of Articles (50-52) of the Civil Code and Article (4) of the Jordanian Companies Law No. (22) of 1997 and its amendments. ${ }^{(30)}$

The Jordanian legislator, like the majority of Arab legislation, has gone against recognizing the criminal responsibility of public law persons (legal persons), as Article (74/2) of the Penal Code stipulates that "moral bodies, with the exception of government departments and official public bodies and institutions, are criminally responsible for the crimes that committed by its directors, representatives or agents in its name or on its behalf."

Based on this text, it was possible to build the criminal responsibility of the legal person, based on the provision of the first paragraph of the same article, which stipulated that the act be consciously and voluntarily. Taking into account that the Penal Code is directed in its commands and prohibitions to humans, it has restricted the imposition of the penalty imposed on legal persons to a fine and confiscation, in accordance with the third paragraph of the same article, which stipulates that legal persons are only sentenced to a fine and confiscation.

It was stated in the interpretation of this on the one hand, that public moral persons are charged with satisfying public needs, and therefore the disruption of these persons results in affecting the needs of people, which are among the necessities that cannot be dispensed with, such as the need for treatment, education, justice or public security, and from On the other hand, there is no point in imposing penalties on these persons or precautionary measures, since the budget of these bodies is part of the state's budget, and therefore imposing fines on them or confiscating their funds is tantamount to the state recovering with its left hand what its right hand provided.

\section{The Second Topic: Compensation of a Legal Person for Moral Damage in Jordanian Law}

Moral harm or non-financial harm, as some call it, means harm that does not affect the financial liability, but only causes psychological and moral pain, because of what it entails affecting the feeling and emotions of man, his honor, honor, dignity, reputation, and social status. ${ }^{(31)}$

The controversy arose over the possibility of compensation for moral damage. At first, the French and Egyptian judiciary refused compensation for moral damage on the grounds of two considerations it deems crucial ${ }^{(22)}$ :

The first is the difficulty of estimating the extent of the moral damage and the amount of compensation that we can give. Honor, dignity and affection of love are not material things for which we find an equivalent or a price in the market according to which compensation for infringement can be determined. In addition to this, the difficulty of determining who is entitled to compensation for moral damage, especially when it comes to with the loss of a dear person, at what degree of kinship should we consider compensation, and whether we can refuse compensation for the harm that befalls the deceased's friend, fiancée, or lover who is not related to him.

$\left({ }^{28}\right)$ Zaki, Mahmoud Gamal El-Din, (1969), Lessons in the Introduction to Legal Studies, General Authority for Amiri Press Affairs, Cairo, p. 479.

$\left({ }^{29}\right)$ Al-Khayyat, Abdel Aziz, previous reference, p. 209

$\left.{ }^{(30}\right)$ The Civil Code and Article (4) of the Jordanian Companies Law No. (22) of 1997 and its amendments, which states that "a company shall be established and registered in the Kingdom in accordance with this law. The kingdom".

$\left.{ }^{(31}\right)$ Al-Far, Abdel Qader, (2004), Sources of Obligation, Sources of Personal Right in Civil Law, House of Culture for Publishing and Distribution, Amman, p. 188

${ }^{32}$ ) Solomon Mark, previous reference, p. 155. 
The second: that grief and sorrow cannot be valued with money, and it is not considered chivalry for a person to demand the price of his grief and pain, or to sell the affection of love that he carries to his relatives and loved ones. borne by the insurer or the insurance company, which leads to higher insurance premiums.

However, despite these criticisms directed at compensation for moral damage, the principle of compensation for moral damage has been established in modern laws, not on the grounds that it is irreparable harm, but on the grounds that it is merely a satisfaction for the injured that provides him with a kind of consolation that relieves him of the pain and grief that befell him. This does not affect the difficulty of estimating compensation for moral damage, as this characteristic is found in compensating a lot of material damage, and therefore the difficulty of estimating compensation does not justify that the person responsible for it escapes from every effect of his responsibility, and the role of the judge remains in overcoming this difficulty ${ }^{(33)}$.

As for the Jordanian Civil Code, it chose to stand by the supporters of compensation for moral damage, explicitly in the text of Article 267 of it, which states that "the right to security deals with moral damage as well. or in his financial consideration makes the infringer liable for the guarantee).

\subsection{The First Requirement: The Concept of Moral Damage}

Moral harm, unlike material harm, does not affect a person's financial interest, but rather affects a non-financial interest, such as mutilating the body, insulting honor, assaulting reputation, and degrading dignity. With regard to moral damage, a distinction can be made between two types of it:

The first: moral damage related to material damage, as is the case in the case of an attack on honor and the consequent loss of his work as a result of polluting his reputation and what may result from an accident of the body being disfigured accompanied by a lack of ability to work, such as the victim losing one of his eyes.

The second: moral harm devoid of any material harm, such as the emotional pain that affects the parents due to the loss of their child, which is a recurring harm incurred by them as a result of losing their child. Investigator, personal and direct so that it can be compensated ${ }^{(34)}$.

The scope of the principle of compensation for moral damage extends to all moral damages. These damages cannot be limited to the conditions of compensation for them. This category of moral damages includes everything that harms a person in his honor, consideration, affection, feelings, identity, privacy or freedom.

An assault on honor or consideration is moral damage because honor does not provide money and compensation for it is symbolic compensation, regardless of its value, and assault on feelings that causes sadness and sorrow in the soul is moral damage that requires compensation and assault on privacy by wiretapping a person is a moral damage on which a liability claim can be established.

Moral damages also include the organic pain felt by the victim, present and future, and psychological pain felt by the victim, such as the pain of disfigurement and the pain of deprivation of the pleasures of life through the impossibility or impossibility of practicing their activities, as is the case in sports and artistic activities, and the pain felt by others due to the death of the injured or What harm befallen him ${ }^{(35)}$.

It is worth noting that the Jordanian judiciary has taken compensation for independent moral damages without the moral damages associated with material damages, and this is illustrated by what the Court of Cassation said about compensation for moral damages resulting from bodily injuries. The concept of the law is the harm resulting from the infringement of a third's freedom, honor, honor, reputation, social status, or financial consideration, according to the provisions of Articles 266 and 67 of the Civil Code. What he suffered from psychological pain as a result of his injury in a traumatic accident, is a departure from the concept of moral damage, because feelings of pain from wounds do not enter into consideration of moral damage" (36).

Referring to the text of Article 267/2 of the Jordanian Civil Code, we find that the legislator has decreed a guarantee for spouses and those close to the family for the moral harm that they suffer due to the death of the victim. Psychological pain in the case of non-fatal injury ${ }^{(37)}$.

Referring again to the same article, we find that even if it expands the scope of the relatives who benefit from

$\left.{ }^{(33}\right)$ Siwar, Muhammad Waheed Al-Din, (1978). Explanation of the Civil Law, The General Theory of Obligation, Involuntary Sources, Dar AlKutub Press, Damascus, p. 21.

${ }^{(34)}$ Jalal Adawi, previous reference, p. 426

${ }^{(35}$ ) Discrimination of Rights, 126/93, Bar Association Journal, 1995, p. 54

$\left.{ }^{(36}\right)$ Adnan Al-Sarhan and Nuri Khater, previous reference, pg. 425.

$\left({ }^{37}\right)$ Nabil Ibrahim Saad, previous reference, pp. 409-410. 
compensation for the psychological damage they suffer as a result of the death of the injured, it does not refer to their right to compensation for the psychological pain that afflicts them when the death of their injured relative is not achieved. On the other hand, the aforementioned article did not refer to a right Other than relatives in compensation for this type of damage, a close friend may suffer from psychological pain more severe than that suffered by the relative due to the death of the injured.

The aforementioned text did not specify who are the closest to the family, which means that everyone who is related to the deceased by kinship within the family, such as a son, father or brother, is considered to be entitled to compensation for the psychological pain he suffers due to his loss.

As for assessing moral damage, its difficulty lies in the fact that it affects a non-financial interest, yet it is compensated with an amount of money, and therefore compensation for it was not accepted in the past, but at the present time, the majority of jurists go to the permissibility of compensation for moral damage as well as material damage, provided that It is achieved on the basis that the real purpose of compensation for moral damage is not to erase and remove it, but rather to provide a kind of consolation for the pain or grief that befell the victim, and if it is not possible to estimate moral damage such as pain, but it is possible to estimate the compensation that compensates to some extent for it.

\subsection{The Second Requirement: Transfer of the Right to Compensation for Moral Damage}

According to the provisions of the Jordanian Civil Code, the right to compensation for moral damage does not transfer to the heirs unless there is an agreement on it between the injured party and the perpetrator of the damage, or a final court ruling has been issued, as stated in Article 267/3 of the aforementioned law which states that "the guarantee shall not transfer for moral damage to third parties unless its value is determined by virtue of a final court agreement or judgment." From this text we note the following:

1) It did not bring anything new, but rather it is a repetition of the general rules, since its existence and its absence achieve the same result that the legislator envisaged, and the detail of this is that if an agreement is made between the perpetrator and the injured party to determine the compensation that the latter deserves, then this agreed amount becomes a fixed right for him in the responsibility of the actor and he is owed to fulfill Likewise, if a definitive court ruling is issued regarding the entitlement of the injured party to the amount of compensation, this amount becomes a fixed right for him in the custody of the perpetrator, and it is obvious that money and rights are transferred by inheritance according to the rules of inheritance and without the need for a text confirming this.

2) He did not recognize the moral damage that befalls non-spouses and relatives, such as a close friend, for example, due to the death of the victim, even though he may suffer more moral damage to his feelings and emotions than the relatives.

3) He did not admit to the spouses and relatives the moral damage that they suffer because of the injured person's injury, disfigurement, or loss of any of his members, although these people may suffer feelings of sadness and sorrow in the event of his injury greater than those suffered at his death.

4) The text limits the scope of the general rule contained in Article 256 of the same law regarding compensation for a harmful act, which stipulates that every harm caused to others is considered a cause for compensation.

The literary right is one of the applications of personal rights that are related to humans due to the privacy and creative nature of the performer's work. Through it, he defends the literary personality of the artist against possible attacks that may occur by third parties and by the owner of the exploitation right. The Paris Court of Appeal went To recognize his right to protect his reputation and consider him associated with the work, which is necessary to protect his personality, and this is completely independent of the financial rights he benefits from. The moral right is defined as one of the rights attached to the personality that includes the protection of the author's personality from any attack that may occur against him, but this definition protects the author's personality absolutely and generality, while the moral right does not protect the author's personality except in relation to the work, while one sees that the literary right expresses About the artist's right to his creativity and the right to respect for his creativity by individuals.

The literary right is one of the most important aspects related to intellectual property, as it focuses on protecting the personality of the performer as a creator and protecting the work as something of intrinsic value regardless of its author. The French, Egyptian and Jordanian legislators have recognized the moral right in this regard.

Article (8) of the Jordanian Copyright Law included the provision of the author's moral rights. As it enumerated those moral rights in its fifth paragraph that the author alone has: "1- The right to have his work attributed to him and to have his name mentioned on all copies...." The text on the author's moral right in Egyptian legislation is also mentioned in Articles 5--6. 7 As the fifth article of it stipulates that "the author alone has the right to decide 
the publication of his work and to determine the method of such publication, and he alone has the right to be financially independent of his work...."(38).

By extrapolating the text of Article 8 of the Jordanian copyright protection legislation, we note that it includes several rights for the author alone over his author, namely:

1) The author has the right to attribute his work to him and to mention his name on all produced copies whenever the work is presented to the public. Article 8 of the Jordanian law stipulates that "the author alone.

2) The right to have his work attributed to him and to have his name mentioned on all produced copies whenever the work is presented to the public, unless the work is mentioned casually during a news presentation of the events.

3) The author's right to publish his work. This was stipulated in Article (8), Paragraph (2) of the Jordanian Copyright Protection Law, which states: "B. The right to decide to publish his work and to specify the method and time of publication." It means the author's right to publish this work, as he has the right, after the completion of his book, to decide whether to publish it or not, and he also decides the date of this publication, except that if the public interest requires otherwise, it will be published even without the author's consent, and this right is limited to The author is alone and subject to his will, and no one can compel him to publish his work or exercise this right on his behalf during his lifetime. That is, after his death, the right to decide to publish the work is transferred to the heirs, as stipulated in Article 12 of the Jordanian Copyright Law, and the publication may be decided by the Minister himself if the public interest so requires ${ }^{(39)}$.

4) The right to withdraw the work from circulation: This right is in contrast to the author's right to publish his work, so he has the right to withdraw this work from circulation if there are serious and legitimate reasons for that. This is stipulated in Article 8/e of the Jordanian Copyright Law: "The author alone has the right to withdraw his work from circulation if there are serious and legitimate reasons for this.

\subsection{The Third Requirement: Extent to Which a Judgment is Permissible to Compensate a Legal Person for Moral Damage}

The nature of the legal person is different from the nature of the natural person, as the legal person refuses to be attributed to him discrimination with which there is an element of awareness in the error. It is the responsibility of the subordinate for the actions of his subordinate, and this responsibility does not require that the component of awareness be available to the subordinate because it is a responsibility that is not based on error ${ }^{(40)}$.

But there may be cases in which it is difficult to consider the person who made the mistake as belonging to the legal person, as if the mistake was a decision issued by one of the bodies of the legal person, such as the company's board of directors or its general assembly, and there are other cases in which the error can only be attributed to the legal person itself as a commercial competition. Unlawful or imitation of a trademark of another company. In such cases and that, the responsibility of the legal person is responsible for a personal action and not the responsibility of the subordinate for the work of the subordinate, and then the fault in the error here is the element or element of the infringement alone without the element of perception, such errors despite their non-issuance On behalf of the legal person directly, due to the impossibility of him carrying out any activity himself, and despite it being actually issued by his representatives from individuals, its raising must go to God alone and not go to them as long as they have committed these mistakes because of or appropriateness of the activity for the account of the legal person and within the limits of their competence by virtue of their representation for him in this activity. The limits of this activity and representation are mistakes, and its effect does not go to the legal person, but rather to the one who committed it from among his representatives.$^{(41)}$

If the harmful act was committed by the member or the subordinate, not in his capacity as a member of the legal person, but in his personal capacity, the legal person is not responsible for that ${ }^{(42)}$, and the injured person has the choice between sue the subordinate on the basis of his responsibility for his personal actions, or sue him on behalf of the legal person based on the responsibility followed by the actions of its subordinates ${ }^{(43)}$.

Based on the foregoing, we note that just as the official responsible for compensation for damage, whether material

${ }^{38}$ ) Arafa, Abdel-Wahhab (1997), Copyright Law No. 354 of 1954 and its amendments, and Digital Works Censorship Law No. 430, Dar AlRadia for Printing

$\left.{ }^{39}\right)$ Kanaan, Nawaf (2009), ibid, p. 90.

$\left.{ }^{(40}\right)$ Ramadan Abu Al-Saud, the mediator in explaining the civil law, previous reference, pg. 370.

$\left({ }^{41}\right)$ Ramadan Abu Al-Saud, the mediator in explaining the civil law, previous reference, pg. 371.

$\left({ }^{42}\right)$ Abdul Hakim Fouda, Civil Compensation, previous reference, p. 165

$\left({ }^{43}\right)$ The same source, p. 164. 
or moral, may be a natural person, the official responsible for the compensation may also be a legal person, as it is possible to question the legal person for his personal actions and refer to him for compensation in Jordan pursuant to Article 256 ) of the Jordanian Civil Code, because the perpetrator or the aggressor person is mentioned in its absolute form in this text and without specification, which indicates that the legislator intended from this release the possibility of the legal person's tort responsibility for his personal actions as is the case for a natural person.

The legal person can also be asked about his personal actions and referred to him for compensation for moral damage in accordance with Article 267/1 of the Jordanian Civil Code, because this text was absolutely in relation to the aggressor and without any specification, meaning that the text includes the responsibility of the natural person and the legal person for moral damage.

Accordingly, the liability of the legal person and the reference to him can be compensated for moral damage, as is the case for a natural person, where the legal person can be held responsible for the dependent's act and refer to him with compensation pursuant to Article (288) of the Jordanian Civil Code.

The Jordanian Court of Cassation affirmed the responsibility of the legal person for the moral damage that he inflicts on the victim as a result of his personal work or the act of the dependent in several of its decisions, as it stated in one of its decisions that: "A mine exploded with a hereditary factor that makes the Ministry of Defense and the General Command of the Armed Forces responsible as the one who laid mines in The area and that it had to take measures and precautions that prevent people from reaching the mine area by surrounding this area with a fence that prevents people from accessing it, and since it did not do so and did not put warning signs, it is responsible for the accident that claimed the life of the plaintiff's legator and responsible for the damages The material and moral incurred by the plaintiffs as a result of the death of their legator" (44).

In another decision of the Jordanian Court of Cassation, it stated: "The Ministry of Education is responsible for ensuring the safety of students during their stay in the school premises, and the officials in the school in which Ibn Al-Mumayaz was studying against them, which is a school specialized for teaching young students, are responsible for the care, supervision and preservation of the students. For their safety and for him, and since the dead child fell from the fourth floor window of the school building because there is no protection iron on that window, the Ministry of Education represented by those responsible for its affairs is responsible for the death of the child and therefore for the compensation that his parents deserve as a result of the death of their child in accordance with the provisions of Article 288 of civil law".

The ruling of the Court of Cassation in its capacity as a human rights advocate No. (2817/2013) stated the following:

We find from referring to the provisions of Article (267/1) of the Civil Code that it states the following: (The right to security also deals with moral damage, every act against others in terms of freedom, honor, honor, reputation, social status, or financial consideration makes the infringer responsible for the warranty).

What is learned from the provisions of this article is that the legislator has permitted the ruling to guarantee moral damage to a natural person if he is caused by an infringement in his freedom, honor, honor, social status, or financial consideration, which means that moral damage affects the natural person and not the legal person.

And since the jurisprudence of the Court of Cassation has established that the basis of moral damage is the infringement that harms the social status of the individual, because every infringement on others in their freedom, honor, reputation, social status, or financial consideration obliges the infringer to guarantee the damage (T. H. 1685/97 Public Authority).

And since the second paragraph of Article (267) of the Civil Code specifies the beneficiaries of compensation for moral damage as a result of the death of the injured spouse and relatives, and did not limit the aggrieved to the heirs, which we see with it that the moral damage does not affect money but affects a non-financial interest, and it can be traced back to the following cases:

Accordingly, the moral damage within the meaning of Article (267) of the Civil Code is for the natural person and not for the legal person. And since the Court of Appeal reached a difference of opinion and ruled against the appellant for moral damage, then its decision is contrary to the law and requires to be reviewed.

It is evident from the judgments of the esteemed Court of Cassation that its jurisprudence is stable, that it is not permissible to award compensation to a legal person for moral damage, because the benefit from the provisions of Article (267) of the Civil Code - according to what its decisions came with - is that (the legislator authorized the judgment to guarantee moral damage to the natural person if he obtained it An infringement in his freedom, honor, honor, social status, or financial consideration, which means that moral damage affects the natural person and not

$\left({ }^{44}\right)$ Discrimination of Rights No. 2677/99, Bar Association Journal for the year 2002, op. cit., p. 1751. 
the legal person.

Referring to Article (51) of the Civil Code, we find that it stipulates the following: (1) The legal person enjoys all rights except what is inherent in the natural character of the human being, within the limits determined by the law. 2. He shall have:

a. Independent financial disclosure.

NS. Capacity within the limits specified by the deed of its establishment or established by law.

NS. Litigation right.

Dr.. independent home. His domicile is the place where his administration center is located. And companies whose main center is abroad and have activities in the Hashemite Kingdom of Jordan, the center of their management, according to internal law, is the place where the local administration is located.

3. He shall have a representative to express his will.

Referring to paragraph (1) of Article (267) of the Civil Code, we find that it states the following: (1) The right to security also deals with moral damage. or in his financial consideration makes the infringer liable for the guarantee).

Thus, what the esteemed Court of Cassation has said about limiting compensation for moral damage in an absolute manner to natural and not moral persons is not correct for the following reasons: Article (51) of the Civil Code stipulates that a legal person enjoys all rights except for what is inherent in a human being. The natural person is within the limits established by law, and therefore the general rule is the equality of the natural person with the legal person in all rights, and the exception is that the legal person does not enjoy the rights inherent in the capacity of the natural person within the limits determined by the law, and the moral damage does not occur in one form, but rather Its forms are multiplied by the number of forms of the right that has been attacked by others, so it is necessary to search for the right that has been attacked by others.

The Federal Court of Cassation, in its decision No. 1650 dated 12/21/2012, ruled that: For their demand to publish a denial of the article published by Al-Alam newspaper on 7/26/2010 and issue 158 under the title "Engineering Report: Abuses and Waste threatening the civil sports facilities in Basra with collapse, and charging them a sum of one billion dinars for defamation and moral compensation for the publication of these slanders in solidarity and solidarity." Article $48 / 2$ of the Civil Code stipulates that a legal person enjoys all rights, except for what is inherent in the capacity of a natural person, within the limits determined by law, and that Article 205/1 of the said law stipulates that it deals with the right to compensation for moral damage as well. In his honor, honor, reputation, social status, or financial consideration, the infringer shall be liable for compensation. Therefore, the claim for compensation for moral damage is the right of natural persons and not legal persons. And since the lawsuit was instituted by the plaintiff, in addition to his position, the court was required to rule that the lawsuit be dismissed from this aspect, and since the distinguished judgment had decided to dismiss the lawsuit for another reason. It was decided to ratify it in terms of the result and to charge the distinguished person a fee of discrimination, and the decision was issued by agreement on Muharram 16/ 1432 AH corresponding to 12/21/2010)

Article (267/1) of the Civil Code stipulates that (the right to security includes moral damage as well. Every infringement on others in their freedom, honor, honor, reputation, social status, or financial consideration makes the infringer responsible for the guarantee. This text clarifies the rights that are subject to infringement, and there is no doubt that some of these rights are established for the natural person without the legal person, such as the right to freedom and the right not to assault honor or honor, as well as the rights that are established for the natural and legal person alike, such as the right In the reputation and the right not to harm the social position and the right not to harm the financial position, the legal person has the right to preserve his reputation, his social position and his financial position from every attack on him by third parties. And her social position and her financial position, and thus she will inevitably suffer material and moral damage.

The jurisprudence has agreed on compensation for moral damage that affects a moral person. Professor Youssef Najm Gibran, the first president of the Court of Cassation in Lebanon, says in his book on the General Theory of Obligations: Public capacity such as the state, municipalities, etc.), and Professor Hussein Amer, former advisor at the Egyptian Court of Appeal, says in his book Civil Liability, which reads: (And the defense of the moral person is not limited to material damage alone, or to what harms the public interests that he represents, but he has a liability Moral, which could cause moral damage, but in relation to reputation and the like, and with the exception of what is related to emotion, such as compensation required by the Postal Authority to repair the moral damage that occurred, by accusing one of its branches of theft unjustly, and in this way to professional syndicates, companies and associations that It has a moral personality, to demand compensation for moral damage that affects its self-confidence), there is no doubt that when someone insults a natural person, the insulted person deserves 
compensation for the moral damage that has been caused to his reputation and position social.

\section{Conclusion}

During his research, the researcher included compensating a legal person for moral damage in Jordanian law through two sections; The first came in defining what is meant by the legal person and clarifying the definition of the legal person, its types and characteristics, the legal nature of the legal person, and the elements of the legal person. In the second topic, it was presented to the compensation of the moral person for moral damage in the Jordanian law by clarifying the concept of moral harm, the transfer of the right to compensation for moral harm, and the extent to which it is permissible to award compensation to the moral person for moral harm. The researcher reached a number of results and recommended a number of recommendations: as follows:

\subsection{First: The Results}

1) A legal personality is a group of people and funds established in order to achieve a specific goal that it is unable to carry out in a specific period of time, which may be long or short.

2) The opinions of the jurists differed about the legal nature of the legal person. Some of them see that the legal personality is nothing but a legal metaphor, while others see it as a realistic fact, its objective element is real, and its formal element is based on the assumption that this group of people or funds are fit to acquire rights and perform duties.

3) The legal person does not enjoy protection and compensation for the moral damage he may cause if the author uses the name of the legal person to publish his work. Deficiencies in the texts of the law that give the legal person appropriate protection for such acts, in addition to his right to compensation for the moral damage he has suffered.

4) With respect and appreciation for what came in the direction of the esteemed Jordanian Court of Cassation on excluding a natural person from the rights contained in Article (267/1) of the Jordanian Civil Code, the researcher found that Article (51) of the Jordanian Civil Code may contradict the court in its direction and aid it in at the same time, by reversing its previous decisions to grant the legal person the rights set forth in Article (267/1) of the Civil Code.

5) The researcher found that moral damage in multiple forms is a research that arises from the act and assault carried out by the aggressor, and as a result it is not appropriate to limit the moral damage to rigid legal texts based on what is stated in the legislation and the decisions of the esteemed Court of Cassation.

6) The theory agrees with the principle of compensation for moral damage, as moral damage in one of its forms is an assault on reputation, financial consideration and intellectual property rights, and it is one of the forms that prove to the moral person one of its manifestations.

7) Compensation for the use of illegal means of the name, trademark and property rights is one of the manifestations of compensating the legal person for moral damage.

\subsection{Second: Recommendations}

1) The researcher recommends the Jordanian legislator to include general provisions clarifying the civil liability of the legal person.

2) The researcher recommends the release of a separate chapter in the civil law to talk about moral damage and its multiple meanings and aspects and how to rule for compensation and claim it.

3) The researcher recommends the Jordanian legislator to reconsider the bases of compensation for moral damage to the moral person.

4) The researcher recommends the Jordanian legislator and the esteemed Court of Cassation to reconsider its position on the rights mentioned in Article (267/1) of the Jordanian Civil Code, as some of these rights are related to the legal person as is the natural person, including reputation.

5) The researcher recommends that scholars and studies specialists conduct specialized studies that clarify the issue of compensating a legal person for moral damage in Jordanian law.

6) The necessity of amending the intellectual property laws related to the rights of the legal person, taking into consideration the position of international agreements and comparative legislation in order to protect their rights such as reputation and commercial status, and compensation for moral damage resulting from the violation of those rights.

7) The researcher recommends the introduction of compensating the moral person for moral damage in the various courts and that this be a firm principle as it does not conflict with legal texts and jurisprudential opinions. 


\section{References}

Abdul, R. A.-S. (n.d.). Mediator in Explanation of the New Civil Law, Theory of Commitment in General, Sources of Commitment (Vol. 1).

Abdullah, M. A.-N. (1995). Literary Damage, A Comparative Study in Islamic and Comparative Jurisprudence. Modern Egyptian Office Press, Dar Al-Marikh Publishing, Riyadh.

Al-Hafiz, A.-M., Fayd, A.-Q., \& Sharh, A.-J. A.-S. (1356 AH). Great Commercial Library (1 ${ }^{\text {st }}$ ed., Vol. 6). Egypt.

Ali, A.-K. (1971). Guarantee in Islamic Jurisprudence, Institute of Arab Research and Studies (Vol. 1).

Decisions of the Court of Cassation, Journal of the Jordanian Bar Association.

Ibrahim, A. et al. (n.d.). Intermediate Dictionary (Vol. 1). Scientific Library, Tehran.

Ibrahim, M. S. (1989). Moral damage and compensation in tort, a comparative study, Master's thesis, College of Law, University of Baghdad.

Ismael, S. (2003). Management's Responsibility for Moral Damage, A Comparative Study. College of Law, University of Baghdad.

Jordanian Civil Law No. 43 of 1976.

Moqaddam, A.-S. (1992). Compensation for Moral Damage in Civil Liability. National Book Foundation, Algeria.

Muhammad bin Makram bin Manzoor the African, Lisan Al Arab, Dar Sader, Beirut, Bab Al-Ra', chapter (AlDhad), part 4.

Muhammad, A. A. (1995). Compensation between material and moral damage and the inheritance. Mansha'at alMaaref, Alexandria.

Muhammad, F. F. (1403 AH-1983 AD). The Theory of Guarantee in General Islamic Jurisprudence (1st ed.). AlTurath Library.

Muhammad, I. E.-D. (n.d.). Estimating compensation between error and damage (pp. 467). Ramses Press, Alexandria.

Saadoun, A.-A. (1981). Compensation for Damage in Tort Liability. Ministry of Justice Press, Baghdad.

Sabri, M. A. (2000). Compensation for Moral Damage in Liability for Mechanical Machines in Iraqi Law, Legal Research Presented to the Iraqi Justice Council for the Purpose of Promotion to the First Class of Judges.

Sahib, A.-F. (2020). Sources of Obligation in Civil Law “A comparative study of Islamic jurisprudence. House of Culture, Amman, Jordan.

Solomon, M. (1992). Al-Wafi in Explanation of Civil Law in Obligations in Harmful Action and Civil Liability (Vol. I, 5th ed.).

Yassin, M. Y. (1991). The Right to Compensation for Literary Damage. Dar Al-Nahda Al-Arabiya.

\section{Copyrights}

Copyright for this article is retained by the author(s), with first publication rights granted to the journal.

This is an open-access article distributed under the terms and conditions of the Creative Commons Attribution license (http://creativecommons.org/licenses/by/4.0/). 